\title{
Quando a Natureza rege: relatos de cantos de trabalho
}

\section{Carlos Gregório dos Santos Gianelli ${ }^{1}$}

Ratoeira bem cantada faz chorar faz padecer

Também faz um grande amante do seu amor esquecer

Laranjeira pequenina carregada de flores, eu também sou pequenina carregada de amores. ${ }^{2}$ (Santos, 2012)

Os versos escritos acima podem não conter a complexidade métrica de um poema de Camóes, ou o jogo de palavras e significados de uma composição de Caetano Veloso, e passam longe da malemolência presente nas mais diversas cançóes de samba. Todavia, eles são um exemplo do que podemos chamar de ajuda ou alívio para o trabalhador rural, o chamado Canto de Trabalho. O Dicionário Musical Brasileiro o define como: "Cantos usados durante o trabalho e destinados a diminuir o esforço e a aumentar a produçáo, os movimentos seguindo os ritmos do canto" (Andrade, 1989, p. 108). Esse tipo de produçáo musical não é comercializado, seja no formato de fonogramas ou de apresentaçôes artísticas. A proficiência técnica musical ou a busca de um padrão estético não fazem parte das preocupaçôes de quem canta. $\mathrm{O}$ canto serve como ferramenta de trabalho, é um dos atenuantes de uma rotina pesada, de

1 Professor de História na rede particular de ensino da cidade de Florianópolis. Mestrando na Universidade do Estado de Santa Catarina (UDESC). Possui graduação em História pela Universidade Federal de Santa Catarina (UFSC).

2 Canto do folclore açoriano entoado pela entrevistada Zilda dos Santos. 
um esforço físico elevado. Essas cançóes geralmente são aprendidas oralmente, com os mais velhos cantando para os mais novos. A origem delas é imprecisa, tendo em vista ainda que, cada vez que se aprende, que se canta a música, muitas vezes é feita alguma alteração ou improviso, que aumenta o labirinto que leva à composição original. No livro "O que é Folclore", o autor Carlos Henrique Brandâo aborda o tema no seguinte trecho relativo a cançóes presentes na soca do arroz no povoado de Santo Antônio dos Olhos D’Água, em Goiás:

Para acompanhar o ritmo do trabalho de "socar o piláo" ela lembra de cantar uma velha cantiga que aprendeu com a mãe e que ninguém sabe ao certo de onde veio, nem de quem. De entremeio com a cantiga a mulher grita para a filha mais velha que não demore em encher de água fresca as cabaças que os homens levarão pro lugar do "eito", penduradas no cabo da enxada. (Brandão, 1985, p. 14)

Muitos dos cantos de trabalho atravessaram as fronteiras das plantaçôes, originando outros estilos musicais, tal qual aconteceu com o blues estadunidense e a música caipira paulista. As worksongs dos negros sulistas dos Estados Unidos foram a principal matéria-prima do que viria a originar o blues: "Antes do blues entoavam-se cançóes para marcar o ritmo do trabalho - enquanto se martelava os trilhos da ferrovia ou se plantava algodão" (Cobb Jr., 2004, p. 125). O negro não cantava por simples distração ou entretenimento, mas para auxiliar na rotina do trabalho pesado. Esse auxílio tinha como consequência direta um alívio para o trabalhador e até mesmo uma melhora na produção da fazenda, como aponta Gilbert Chase:

Nem o dono da fazenda, nem o feitor se importavam de que os escravos cantassem, desde que fizessem o trabalho. O canto podia ser até visto com bons olhos, pois que tendia a aliviar o peso, o tédio da labuta e, assim, a tornar os negros mais dóceis, mais satisfeitos; o que equivale a dizer, do ponto de vista do dono da fazenda, menos incômodos. (Chase, 1957, p. 61)

\section{Catulo e Cantalício}

Os relatos presentes neste artigo foram colhidos no município de Guaramirim, região norte do estado de Santa Catarina. Os possíveis erros 
gramaticais cometidos durante as falas foram preservados para aumentar a fidelidade da transcrição. A entrevistada Zilda Flores dos Santos, hoje professora aposentada, contou-me sobre as cantigas entoadas na colheita do café e na raspagem da mandioca no período de sua infância, quando nas férias escolares ajudava a família e os empregados na função. O outro entrevistado, Daniel Graudin, revela uma vertente interessante do canto de trabalho na regiáo: a presença da imigração russa. Os versos que iniciam este texto foram cantados por Zilda, que fez questão de separar ou destacar a canção dentre tantas outras:

Ó Gregório, essa aqui a gente cantava muito, desde que eu era bem pequenininha, né? Tô com setenta e quatro (anos). Quando eu era pequena, eu já escutava cantar, já cantavam, né... [depois de cantar a música]: Isso era uma coisa que a gente cantava muito. Cantiga de roda, cantiga na roça. Tudo que a gente lembrava, tanto cantiga de roda como folclórica, a gente cantava na colheita do café. Que era só em junho e julho. Em julho que a gente ia por causa das férias. ${ }^{3}$ (Santos, 2012)

O destaque dado para uma canção em específico permite a reflexão sobre outro aspecto presente nessa e em muitas outras entrevistas, a questão da saudade. Gostamos de nos lembrar daquilo que nos fez bem. É verdade que nos recordamos das coisas ruins, mas, no momento em que é requisitada essa visita ao passado, quando temos que expor algo através da memória, do relato, a saudade impera, trazendo consigo o que pode ser visto ainda como positivo para o tempo atual. Ivone Gebara, em seu recente trabalho, "O que é saudade", toca a questão, trazendo, dentre outras definiçóes, a seguinte:

A saudade recupera tempos, reinventa-os, modifica-os. A partir de nossos desejos circunstanciais e de nossas emoçóes, reinventa cada narrativa sobre o tempo passado e sobre a nossa história presente. (Gebara, 2010, p. 16)

A seleção do que é dito, a modificação que se pode ter sobre a realidade através da narrativa, a ênfase em determinado assunto, tudo isso acaba passando através do prisma da saudade.

3 SANTOS, Zilda Flores; GRAUDIN, Daniel. Entrevista concedida a Carlos Gregório dos Santos Gianelli, em 20 de fevereiro de 2012. Guaramirim/SC. 
No momento da entrevista, Zilda dos Santos já conhecia o meu apreço pela temática de cançôes envolvendo cunho político. ${ }^{4} \mathrm{Com}$ isso em mente, ela seleciona, dentre os cantos de trabalho, cantigas de roda e poemas os seguintes versos:

Senhor, senhor, senhor capitão, cadê o dinheiro da nossa nação?

Eu não tenho dinheiro, eu não tenho mais nada, só tenho o boné e a minha espada. ${ }^{5}$ (Santos, 2012)

Após cantar, Zilda, seguindo o seu instinto de professora, faz questão de explicar o tipo da música cantada, explicitando qual a temática envolvida nos versos e, para melhor compreensão do entrevistador, ela relaciona a cantiga com a minha pesquisa:

Então era isso que era a coisa popular que eles tiravam. Não é bem usavam, mas aproveitavam a história que tava acontecendo e faziam a modinha, como faziam Alvarenga e Ranchinho na época do Getúlio (Vargas). ${ }^{6}$ (Santos, 2012)

Com esses dois exemplos, já se pode identificar a inexistência de um padrão temático envolvendo as músicas cantadas na colheita do café na fazenda do avô de Zilda, em Guaramirim. Poderia ser tanto uma canção do folclore açoriano, que em sua letra carrega a temática do amor, ainda que de modo simples, como uma canção tratando de temas políticos e sociais, como aparece na cantiga em que o trabalhador requer o dinheiro dado pelo povo para a manutenção do Estado.

As entrevistas para este artigo foram realizadas na casa do historiador-amador Daniel Graudin, em Guaramirim. Daniel guarda muitos documentos e fotos antigas de sua família, de origem russa, e de sua falecida esposa, Zilma Flores, tia de Zilda dos Santos. O acervo documental de Daniel Graudin ajuda na construção da memória e da história do município. Não é

4 Atualmente desenvolvo no mestrado em História, na UDESC, uma pesquisa sobre a produçáo musical da dupla caipira Alvarenga e Ranchinho.

5 Cantiga cantada por Zilda dos Santos.

6 SANTOS, Zilda Flores; GRAUDIN, Daniel. Entrevista concedida a Carlos Gregório dos Santos Gianelli, em 20 de fevereiro de 2012. Guaramirim/SC. 
por menos que, cerca de um mês após a realização da entrevista, seria inaugurado o primeiro museu da cidade, contando com a imensa participação de Daniel, tanto na área de pesquisa quanto no fornecimento de documentos, fotos e objetos pelo historiador. Zilda fez questão de me acompanhar até a casa dele, pois lembrava que Daniel poderia ter guardado em algum lugar de sua casa um pequeno caderno contendo o registro de algumas das cançóes cantadas por ela e sua família. Após revirar muitas fotos e livros antigos, dentre eles muito material que pode ser desbravado e aproveitado por pesquisadores de diversas áreas, como, por exemplo, um livro didático que se propunha a ensinar português a imigrantes alemães datado de 1896, Zilda finalmente achou um pequeno caderno com muitas cantigas e poemas escritos à mão por seu avô Cantalício.

Cantalício Érico Flores, sogro de Daniel Graudin, foi o primeiro intendente de Guaramirim, cargo no qual exercia diversas funçóes, de delegado de polícia a administrador do Núcleo Colonial Barão do Rio Branco. Mais tarde, dentro desse Núcleo, Cantalício exerceu a profissão de professor e farmacêutico. Folheando o caderno de cançóes do ilustre guaramirense, pude reparar que um de seus compositores favoritos era Catulo da Paixáo Cearense. Partindo dessa observação, descobri mais fatos curiosos do homem multitarefa que atualmente é homenageado com o nome da principal praça de Guaramirim:

Carlos Gregório: O Catulo era um dos favoritos do seu Cantalício? Zilda: Era, era..

Daniel: Porque na época era ele o "can-can”. Hoje quem é? É o Roberto Carlos...

Zilda: Ele era um dos mais porque não cantava só folclore, mas cantava história, amor, cantava cultura.

Carlos Gregório: E o Cantalício conhecia as músicas do Catulo como?

Zilda: Não por gravação, porque não existia. Era por alguém que vinha pro Rio Branco (atual Guaramirim) e cantava pra ele.

Daniel: (interrompendo) Não, não, a maior parte era por jornais! Zilda: E o vovô ele estudou em Florianópolis, Farmácia, antes de vir pra cá. Então lá que ele teve muito conhecimento de músicas.

Daniel: Porque ele tem a foto aqui (me mostra uma foto de Cantalício com um bastão de caminhada, um tipo de bengala, elemento de indumentária 
típico dos seresteiros dos anos de 1920 e 1930) Ele era um... como é que dá o nome das serenatas..

Carlos Gregório: Seresteiro?

Daniel: Seresteiro! Ele era um seresteiro. Ele, o Leoberto Leal que foi deputado, governador do Estado (na verdade foi duas vezes deputado) Nereu Ramos que era de Lages, mas estudava e morava em Florianópolis, Tijucas...Tijucas era o centro dessas coisas...

Carlos Gregório: Qual a época do Catulo?

Daniel: Ah, eu acho que... era anos 40, Catulo foi $40 \ldots$

Zilda: É eu acho que foi até 40, 45, depois começou a entrar o Rádio mais forte né... (Gianelli;Graudin;Santos, 2012)

O aprendizado das cançóes entoadas na lavoura do café da fazenda do avô de Zilda funcionavam nesse esquema de dispersão cultural. Cantalício Flores, na sua época de estudante de farmácia na capital catarinense, aprendia as cançóes ao sair pela cidade com outros seresteiros e as levava para Guaramirim. Para assegurar a permanência das cançóes, ele as escrevia em seu caderno, tomando cuidado tanto no capricho com a ortografia quanto na organização do material, numerando todas as páginas.

Algumas das cançóes têm no seu final a data em que foram registradas, que varia de 1904 até 1930. Pedi para que Zilda separasse algumas das cançóes mais entoadas. Depois de anotar as páginas das cançóes selecionadas, pedimos a permissão de Daniel para fazer a cópia do material. Dentre as músicas escolhidas, está Meu Ideal, de Catulo. Ao verificar a letra com outras versóes, percebi o que corriqueiramente acontece ao se passar essas cançóes para outras geraçóes: a mutação da letra. São apenas duas palavras diferentes, no entanto, já se percebe a modificação. O motivo da mudança pode ser diverso, Cantalício pode ter aprendido daquele jeito, pode ter escutado por engano aquela troca de palavras, pode ter achado que determinada rima caberia melhor ao verso, enfim, são inúmeras as possibilidades. Peter Burke, em seu livro "Cultura Popular na Idade Moderna”, reflete sobre essas modificaçôes presentes na cultura popular, comparando-as com os boatos:

Na cultura popular, a variação individual, tal como variação regional, deve ser vista basicamente em termos de seleção e combinação. Combinar fórmulas e motivos e adaptá-los a novos contextos não é um processo mecânico; na verdade, "toda boa improvisação é um ato criativo." Mas a 
variação ocorre não só em virtude de atos criativos individuais conscientes, mas também de maneira inconsciente." As baladas se parecem com boatos", como diz um folclorista americano." A variação delas surge de modo muito semelhante e só transmitem o que lhes interessa, de maneira que um boato, ou uma balada, se torna progressivamente mais curto à medida que vai perdendo tudo o que não é memorável. (Burke, 1999, p. 170)

Qualquer que seja o motivo da alteração, ela vem a contribuir para a riqueza de versóes que existem nas cançôes folclóricas ou que já se consagraram no cancioneiro brasileiro. As alteraçóes ou omissóes de versos feitas por Cantalício estão em itálico, com a outra versão entre parênteses:

Meu Ideal - Canção

$1^{\text {a }}$ parte

Pudesse esta paixão / Na dor cristalizar / E os ais do coração /Em pérolas congelar / De tudo o que sofreu/ Na tela deste amor / Faria ao nome teu /Divino resplendor

Pudesse est'alma, sim (assim), / Com a tua entrelaçar / E aos pés de Deus / Num surto ao fim voar / E as nossas almas transmutar / Numa só alma /De um insonte cherubim (querubim)

$2^{\mathrm{a}}$ parte

Lá, lá nos céus então / Contigo ali do amor / Na pura e etérea floração / (Lá, junto a Deus então Cantar uma canção De adoração a ti) Lá eu diria aos pés do Redentor / Perante os imortais: / Senhor, eu venero muito a ti / Mas confessor sem temor / Que a ela eu amo mais

$3^{\text {a }}$ parte

Minh'alma ascende além/ Que Deus já te esqueceu / E as almas (terras) não contém / Afeto igual ao meu (teu) / Procuras, mas em vão/ $\mathrm{Na}$ térrea solidão / Achar as pulsaçôes (ouvir a pulsação) / Do coração do amor / Num raio inspirador / No plaustro do luar / Percorre o céu, o inferno/ A terra e o mar / Não acharás, não acharás / Amor igual / Ao meu amor (que o teu amor) / Que é imortal (é imortal) ${ }^{7}$ (Flores, p.53-54)

7 Caderno de canções de Cantalício Érico Flores, p. 53-54. Acervo pessoal de Daniel Graudin. 
Outra canção separada por Zilda dos Santos é a modinha Cabocla Bonita, também da autoria de Catulo. Como se poderá verificar na letra, a temática da canção também gira em torno do amor.

Cabocla Bonita (Catulo)

I

Quando tu sambas no samba, meu bem!

Parece um beijaflozinho

Voando de flor em flor, meu bem

A procura do seu ninho

Ah! Cabocla bonita me dá um beijinho

II

Quando tu vens lá de longe, meu bem!

Eu aqui adivinho

Tu fazes estremecer, meu bem!

As cordas deste meu pinho

Ah! Cabocla bonita, me dá um beijinho.

III

Quando tu vens lá da mata, meu bem!

Cantando pelos os caminhos,

Vai seguindo atrás de ti, meu bem!

Um bando de passarinhos

Ah! Cabocla bonita, me da um beijinho...

IV

Quando nasceres dos anjos, meu bem!

Eu quero ser teu padrinho

Dou-te a mão de Deus, meu bem!

Como a um cordeirinho

Ah! Cabocla bonita, me dá um beijinho

$\mathrm{V}$

Ah! Se eu tivesse a aventura, meu bem!

De te dar um beijinho 
Seguia atrás de ti, meu bem

Como um cordeirinho

Ah! Cabocla bonita, me dá um beijinho

Fim $^{8}$ (Flores, p.41-42)

É possível observar nas duas canções a referência ao divino. $\mathrm{Na}$ canção Meu Ideal, o compositor presta contas a Deus por adorar a sua musa, quando diz: "Senhor, eu venero muito a ti / Mas confesso sem temor/ Que a ela eu amo mais" (Flores,p.53). ${ }^{9}$ Essa mesma característica está presente na modinha Cabocla Bonita, quando além da referência a Deus, o compositor evoca os anjos como símbolo máximo de beleza carregado por sua cabocla: "Quando nasceres dos anjos, meu bem!/ Eu quero ser teu padrinho/ Dou-te a mão de Deus, meu bem! / Como a um cordeirinho / Ah! Cabocla bonita, me dá um beijinho."(Flores, p.41) ${ }^{10}$

Além da lavoura do café e da raspagem da mandioca, nos momentos de descanso, como depois do almoço, também eram entoadas cançóes. Aqui o canto exerce uma funçáo um pouco diferente da de dar ritmo ao trabalho na roça, do bater de enxadas ou do corte do facão. O Canto de Trabalho também serve como modo de descanso dentro da jornada de trabalho. Depois do almoço, os empregados, antes de voltarem para o trabalho na roça, dirigiam-se a uma área na frente da casa e espontaneamente assoviam, cantavam e tocavam ao violão diversas cançóes para entretenimento, como explica Daniel:

Daniel: Era de meio dia, você almoçava, os empregado que nem nóis, tinha oito, dez empregado sempre na casa da vó quando eu conheci nos anos 40 em diante. Eles acabavam de almoçar tinha uma área grande na frente, eles sentavam na área e ai tinha um violão. Aí um cantava e outro assoviava, daí um cantava lá e o outro respondia daqui... Era sempre trovas e os cantos individuais e as trovas e as duplas. Isso era muito comum na época, isso é tudo parte açorianas. ${ }^{11}$ (Graudin, 2012)

8 Ibidem. p. 41-42.

9 Ibidem. p. 53.

10 Ibidem. p. 41.

11 GRAUDIN, Daniel. Entrevista concedida a Carlos Gregório dos Santos Gianelli, em 20 de fevereiro de 2012. Guaramirim/SC. 
A tradição oral, presente na maneira como Cantalício aprendeu as cantigas nos tempos de seresteiro, cantigas essas que mais tarde traria para Guaramirim, encontra-se com a tradição escrita no momento em que ele se preocupa em registrar tais cançóes em um caderno devidamente organizado. Esse tipo de preocupação do seresteiro com a preservação e perpetuação das cantigas ajuda a compor o quebra-cabeça dos cantos de trabalho. Por serem muitas vezes cançôes apenas cantadas, e nunca registradas suas letras e muito menos enquadradas dentro de uma partitura musical, as fontes históricas se dão em sua maioria por resquícios como esses, deixados em pequenos registros. Bom seria para os pesquisadores se a maioria dessas cançóes tivesse sido registrada com o cuidado de Cantalício.

\section{Os russos}

Logo no início da conversa com os entrevistados Zilda dos Santos e Daniel Graudin, já quis entrar no assunto deste artigo, os Cantos de Trabalho. Antes de a entrevista ser realizada, anteriormente à minha viagem para Guaramirim, pensei que existiria um padrão homogêneo entre os cantos. Essa impressão já foi quebrada logo nos primeiros minutos de conversa, com uma rica revelação por parte de Daniel Graudin sobre seus avós:

Carlos Gregório: E como eram os cantos lá nas terras do seu avô?

Daniel: Ah, lá eram os Russos...

Carlos Gregório: E eles cantavam pra fazer as colheitas?

Daniel: Aí tu tem os cantos letos..

Carlos Gregório: Era um canto totalmente diferente dos cantos da dona Zilda?

Zilda: Era...

Carlos Gregório: O que vocês cantavam (Zilda)?

Zilda: $\mathrm{O}$ nosso era mais sertanejo, modinha...

Carlos Gregório: E o de vocês? (para o Daniel)

Daniel: O nosso não era (sertanejo), era folclórico russo.(Gianelli; Graudin; Santos, 2012) 
Tomado pela curiosidade de saber como seria a vida desses imigrantes russos em Guaramirim, fiz algumas perguntas para Daniel. Um assunto como esse, envolvendo música, arte, envolve muito o lúdico. Enquanto o entrevistado falava, minha imaginaçáo ia longe, imaginando os russos trabalhando em lavouras catarinenses, cantando suas músicas em seu idioma original para ajudar na labuta das terras recém-adquiridas. Refleti também sobre como o canto de trabalho, além de ser uma ferramenta para suportar o trabalho pesado no campo, pode ser encarado como afirmador cultural. Através desse canto, por exemplo, identificar-se-ia esse grupo russo, seja pelo idioma, que seria de mais fácil percepção, seja pelo ritmo das músicas, a afinação, a temática, enfim, um silogismo musical que ajudaria na afirmação cultural daquele povo ali inserido, completamente fora do seu contexto original. Para melhor compreensão de quem seriam esses imigrantes, fiz algumas perguntas para Daniel que poderiam ajudar a traçar um perfil básico desses russos e de seu trabalho por aqui:

Carlos Gregório: Quem eram esses russos que vieram para Santa Catarina no início do século XX?

Daniel: Eram tudo pessoas bem instruídas que vinham, não eram assim pé de chinelo que chegavam aqui. Era muito pouquinho pé de chinelo, assim que tinha menas (sic) instrução. Tudo eram pessoas estudiosas, pessoas que tinham se formado em grandes estudos e profissóes. Todos eles tinham suas profissóes, sabe? Se eles queriam montar esse rádio (aponta para o micro system na estante da sala), digamos que tinha isso, eles pegavam e montavam esse rádio qualquer um chegava e montava isso aí. Hoje chega prum rapaz nosso ele não sabe o que é aquele botão, sabe porque trabalha muito na internet essa coisa...Eles tinham muita instruçáo. Eles tinha tudo, sabia montar um engenho de farinha, um engenho de açúcar, uma coisa que hoje não temos mais nada, tá morrendo tudo... (Gianelli;Graudin,2012)

Para voltar o foco da entrevista para os cantos de trabalho, perguntei a Daniel sobre a lavoura dos russos ali e as diferenças em relação ao seu local de origem. Fiz essa pergunta devido à estreita relação presente entre o que é plantado e o que é cantado:

Carlos Gregório: E o que eles plantavam lá na Rússia era o mesmo que eles plantavam aqui? 
Daniel: Não, eles vieram com esse pensamento que dá pra plantar tudo que era de lá e trazer pra cá. É onde eles se lascaram [...] Eles chegaram aqui e levaram uma, porque os Russos eram tudo terra de sequeiros. E eles vieram, chegaram aqui e era tudo alagadiço, terras alagadiças pra plantar arroz. E não era isso, arroz é pra japonês! Não é pra russo! Russo só quer terra de sequeiro.

Carlos Gregório: E o que eles plantavam?

Daniel: Eles só plantam trigo e cevada, e beterraba como açúcar, pra ser açúcar, o que hoje é a cana era a beterraba. E para o seu sustento, a maior força era o repolho. Era a couve e o repolho os principais.

Carlos Gregório: E o que foi substituído da cevada e do trigo, foi o arroz? Daniel: Não, e por causa disso nós temos um cemitério com mais de 80 crianças mortas ali. Que as crianças não se adaptaram com a comida que tinham lá com a que tinham aqui, palmito, comer aipim, lá não se via isso, nunca ninguém viu.

Zilda: Tá, mas aí qual era a plantação que eles plantaram?

Daniel: Aí começaram a plantar o taiá...

Carlos Gregório: $\mathrm{O}$ arroz?

Daniel: Não, o arroz veio depois, o arroz só veio em vinte e pouco. Até ali não tinha arroz. A lavoura mesmo, a força da vida deles aqui era a madeira. A venda da madeira, madeira para exportação. Esse era o que eles ganhavam um dinheirinho.

Zilda: Mas, o que eles plantavam pra comer?

Daniel: Aí foi o taiá, foi o aipim, foi a batata doce que ganharam as mudas pra plantar do governo. E o governo passava e deixava lá na comunidade, dois sacos de feijão, três de arroz. (Gianelli; Graudin; Santos, 2012)

Adiante, com o objetivo de traçar alguns pontos que demonstrassem as diferenças entre os cantos de trabalho dos russos e dos brasileiros, perguntei para Daniel se havia modificação nas músicas entoadas pelos imigrantes, tendo em vista a transformação na cultura da lavoura:

Carlos Gregório: Eles cantavam essas músicas pra plantar, por exemplo, a cevada e o trigo lá na Rússia, e eles cantavam essas mesmas músicas pra plantar o taiá aqui então?

Daniel: É... quando eu me criei ali anos 40, quando você ia na roça, você tinha os vizinhos assim perto, entáo você escutava toda vida... Era sempre, 
se você se colocasse aqui num domingo de tarde, umas dez crianças ou dez rapazes assim de vinte anos, trinta, quinze anos, os casados. Se juntava tudo ali, era Pedro Malazarte a história que contava! (risos) Contava a história de Pedro Malazarte, se tivesse um violão, pronto. Ali já era o ponteado, já era as modinhas que eram tocado e cantado, aí cantava aquelas dupla. Era, era... era uma coisa de louco. Tudo lugar você via, você podia escutar na roça. O seu Jacinto tá na roça com a família. Ficava lá o velho (Daniel assovia uma melodia) assoviava o assobio. (risos) Dois quilômetros você ouvia o assovio do cara! E as meninas começavam: "José e Maria se amavam... não sei o que lá..." Cada um fazia a sua... E então sempre cantavam, sempre a goela tava aberta pra cantar tudo. (Gianelli; Graudin, 2012)

Essa relação presente entre a cultura da lavoura e a música cantada é possível de ser observada e analisada quando nos deparamos com gravaçôes de áudio ou de vídeo dos cantos na roça. O cineasta e documentarista brasileiro Leon Hirzman fez, nos anos 1970, uma trilogia de documentários denominados Cantos de Trabalho. O primeiro dos três filmes, de 1975, chamado Mutirão, mostra o trabalho coletivo para a construção de uma casa em Chã Preta, região de Viçosa, em Alagoas. ${ }^{12}$ Nele, é possível observar que muitas das vocalizaçóes são feitas apenas com o canto de vogais de tempo longo, prevalecendo um longo "o". Geralmente é nessas vocalizaçóes que entram outras vozes harmonizando em intervalos de terças e quintas, semelhantes às presentes na música caipira e sertaneja. $\mathrm{O}$ ritmo do canto tem como seu regente o bater da enxada, que serve de metrônomo para a canção. $\mathrm{O}$ tempo forte de cada compasso é dado no mesmo instante em que a enxada toca o solo da lavoura. Outra característica que é possível observar nos cantos de trabalho desse primeiro documentário da trilogia é a presença de vocais de reposta em relação a um principal. Outro ponto forte com relação ao ritmo das cançóes é a precisão do tempo, quase não havendo variação de andamento, prevalecendo o ritmo do compasso binário (Hirszman, 1975).

O segundo documentário, Cacau, filmado na região de Itabuna, Bahia, documenta os cantos presentes na extração do fruto. ${ }^{13}$ Nele aparece um novo elemento, que além de ditar o ritmo da canção, gera mais uma representação

12 Informação disponível em: http://www.leonhirszman.com.br/ Acesso dia 03 de março de 2012.

13 Idem. 
cultural da localidade. A pisa do cacau, além de marcar o tempo, traz com seus movimentos a dança para o canto e a música (Hirszman, 1976a). Encerrando a trilogia, o documentário Cana-de-açúcar registra os cantos das lavouras de cana na região de Feira de Santana, Bahia. ${ }^{14}$ Nesses cantos da colheita da cana, é possível observar a relação presente até mesmo nas ferramentas utilizadas na lavoura para a construção de uma identidade sonora. Enquanto a música é cantada, os facóes utilizados para cortar a cana-de-açúcar são batidos um contra o outro como em um duelo, dando o ritmo e acrescentando um timbre novo, um som agudo de percussão, semelhante ao triângulo utilizado no baião (Hirszman, 1976b). A variação presente nos cantos de trabalho de cada lavoura em cada região é assinalada por Peter Burke:

Se a cultura surge de todo um modo de vida, é de se esperar que a cultura camponesa varie segundo diferenças ecológicas, além das sociais; diferenças no ambiente físico implicam diferenças na cultura material e estimulam também diferentes atitudes. A ilustração mais óbvia desse aspecto é, certamente, o contraste entre a cultura das montanhas e a cultura das planícies. (Burke, 1999, p. 57)

Ainda com relação aos russos, perguntei para Daniel como eram aprendidas essas músicas, como eram passadas de geração em geração, se existia algum registro dessas cançóes e qual o tema geral delas:

Carlos Gregório: essas músicas do folclore russo, eles aprendiam elas oralmente ou tinha livro, caderno?

Daniel: Não, tinham livros, livros.

Carlos Gregório: Mas vinham livros da Rússia com as músicas?

Zilda: Eles traziam.

Daniel: A maior quantidade de livros foi queimado tudo aquela vez que pegou fogo lá na cozinha queimou, tinha caixôes de livros todos folclóricos. Carlos Gregório: Qual era o tema das letras dos russos?

Daniel: Os russos se baseavam mais na religião.

Carlos Gregório: Eram letras religiosas então?

Daniel: Religiosas, daí completavam com a vida normal e tudo. Mas, sempre tinha um cunho religioso.

Carlos Gregório: Os russos que cantavam essas músicas aqui eram de qual religião? 


\section{Daniel: Eram Batistas. \\ Carlos Gregório: Batistas? \\ Daniel: Batistas e Luteranos. (Gianelli;Graudin;Santos,2012)}

Diferentemente das canções conhecidas por Cantalício - seresteiro que aprendia as músicas na boêmia e depois registrava em seu organizado caderno as modinhas e toadas que iria ensinar à família -, os russos da família de Daniel Graudin traziam livros com as cançóes folclóricas devidamente registradas. A grande perda documental ocorrida com o incêndio relatado mostra o triste exemplo de como tais fontes, relacionadas à cultura popular, como no caso em específico, aqui, dos cantos de trabalho, sofrem com a falta de preservaçáo ou ainda com o infortúnio de acidentes, que fazem com que grande parte do material desapareça completamente. Outro ponto a ser analisado no relato de Daniel é o cunho religioso presente nas letras folclóricas. Apesar de, nos exemplos mostrados, as letras de Catulo possuírem alguma relação com o divino, a temática do amor prevalece. Já nos cantos dos russos, a temática religiosa impera, tendo como base doutrinária e religiosa o protestantismo das igrejas batistas e luteranas. Finalizando essa parte da entrevista, Daniel surge com mais uma novidade. Ele afirma que os russos também cantavam pagodes, ritmo típico da música sertaneja que, no ponteio da viola, conta uma história ou propóe um desafio entre duplas, na sua rotina de trabalho, no entanto sem abandonar a língua materna:

Daniel: Eles tinham livros de pagode também. Eles tinham também de fazer pagode um do outro (risos). Eles tinham também!

Carlos Gregório: Os russos?

Daniel: Eu tenho também, tá lá no Museu. Ta lá os russos tocando e eles tavam fazendo pagode.

Carlos Gregório: Mas, era em russo?

Daniel: Em russo...

Carlos Gregório: Imagina um pagode em russo! (Gianelli;Graudin, 2012)

\section{O desafio do método}

Este artigo sobre Cantos de Trabalho teve, carregado em si, o desafio metodológico de se utilizar de fontes orais. A cultura popular e os cantos 
de trabalho são carentes de fontes de estudo. Geralmente se utiliza algum registro escrito, seja um livro contendo cançóes, um jornal compilando baladas e poemas ou, como foi o caso deste trabalho, um organizado caderno do início do século XX. Outra fonte rica, quando se trabalha com o tema, sâo as fontes orais. Nas entrevistas, é possível registrar, além da letra propriamente dita, a melodia, o tom, o ritmo das cançóes, que em muitos casos não seguem as regras ou normas musicais eruditas. A história oral ainda contribui com os estudos de música e história por ser uma metodologia que possibilita a democratização, propiciando, a quem muitas vezes não tem voz, a representatividade necessária para aparecer em algum livro. Alessandro Portelli, durante uma conferência denominada "História Oral e Poder", no XXV Simpósio Nacional de História, realizado na cidade de Fortaleza, no ano de 2009, lembra que uma das principais funçôes da história oral é a de incluir determinados grupos sociais no discurso histórico. "Este é um trabalho político", afirma o pesquisador italiano (Portelli, 2009).

Portelli também ressalta a importância do trabalho em campo na pesquisa do historiador que utiliza fontes orais. Para o presente artigo, esse ponto foi de suma importância, pois foi somente com o trabalho em campo e com o desenrolar das perguntas que cheguei ao assunto relacionado ao Canto de Trabalho dos russos na região de Guaramirim, Santa Catarina. Até então, confesso que não sabia da existência de uma leva de imigrantes russos para a regiáo e muito menos de seus cantos na lavoura. Foi somente no momento da entrevista que fui descobrir essa faceta, cabendo a mim, como historiador, propor novas perguntas, com novos questionamentos ao entrevistado Daniel Graudin.

A experiência em campo traz ao historiador, além do registro de áudio, o registro das expressóes de seus entrevistados. Quando se tem a possibilidade de fazer um registro audiovisual, essa característica pode ser melhor transmitida para mais pesquisadores. No entanto, no meu caso e no de várias pesquisas, ficam registradas somente as fontes sonoras. Todavia, para quem fez a entrevista, ficam guardadas na memória as expressóes dos entrevistados, as pequenas ênfases em determinado assunto, o peso na voz em determinado episódio. A fonte oral, entáo, carrega em si esse diferencial de interpretar a fonte náo somente na camada superficial da informação ali contida no relato, mas de perceber que ela se desdobra em outras camadas, aumentando a possibilidade de reflexões sobre o mesmo tema. 
Um dos principais diferenciais da utilização da fonte oral para o trabalho de pesquisa é a mudança no estilo da escrita do pesquisador. $O$ já estabelecido monólogo acadêmico, no qual somente o autor tem voz, na maioria das vezes utilizando outros referenciais para enriquecer a sua fala, dá lugar ao diálogo entre o entrevistador e o entrevistado. $\mathrm{O}$ momento em que se colocam os relatos e as impressóes do pesquisador deve ser de divisão de narrativas. Por isso, fiz questão de relatar, por exemplo, o meu fascínio com relação ao novo assunto que surgiu na pesquisa de campo: a presença dos russos na região. Fiz questão de esclarecer que uma das entrevistadas, como já sabia do meu trabalho de pesquisa com sátira política, insistiu em separar modinhas e versos com essa temática. Como Portelli expóe em sua conferência, as informações não devem ser somente extraídas do entrevistado, mas compartilhadas. Minhas impressóes, expressóes, meus anseios e minhas dúvidas devem ser colocados a par das informaçóes que estão sendo passadas a mim, tendo em vista que serão eles que moldarão o trabalho final. Saber o que mais me impressionou, o que me chamou atenção, o que me despertou a curiosidade ou até mesmo o que me causou alguma repulsa, ajudará o leitor, seja ele um pesquisador ou não, a compreender de maneira mais ampla todo o trabalho feito. $\mathrm{O}$ historiador que se utiliza de fontes orais náo pode se colocar no patamar superior de quem achou uma "pepita de ouro" de informação no meio de um relato daqueles que não tem voz. "Não somos nós que damos voz a eles, mas eles que nos dão voz e nos permitem escrever livros", ${ }^{15}$ afirma Portelli.

Em seu livro "História: A arte de inventar o passado", Durval Muniz de Albuquerque Júnior provoca de certa forma os historiadores com um dos seus ensaios intitulados: "As dobras do dizer: da (im)possibilidade da história oral” (Albuquerque Jr., 2007, p. 229). A provocação, que também serve para reflexão, gira em torno da ideia de que a história oral, de uma maneira geral, reafirma o poder da escrita:

A História é mais um artefato que reafirma a dominação dos que escrevem sobre os que falam. Embora esteja hoje aberta aos perigos da fala, aos perigosos que falam e falaram no e sobre o passado, continua fechada à possibilidade de violaçáo de suas regras, apegada que está ao fato de quem é um saber por escrito. (Portelli, 2009)

15 PORTELLI, 2009. 
Em uma primeira observação, a crítica parece ser feita à metodologia da história oral, considerada ineficaz e pouco produtiva. No entanto, enxergo a crítica de Durval mais voltada aos historiadores do que ao método em específico. Cabe a cada pesquisador que expóe o seu trabalho com fontes orais esclarecer o valor de sua fonte e não usá-la somente como base argumentativa para a sua problemática. Um dos entrevistados para este artigo, Daniel Graudin, comenta essa sensação de superioridade por parte de quem escreve ao fazer pesquisas relacionadas à cultura popular:

Daniel: As coisas antigas, o folclore mesmo, tudo. Tá morrendo tudo, se não começar a buscar isso, a buscar no fundo...

Zilda: As origens, né?

Daniel: As origens nossas, nós vamos se acabar em nada. Nós vamos se acabar em nada. E aí procurar aonde? Algum chega lá e conta, escreve um livrozinho... (Graudin; Santos, 2012)

\section{Referências}

ALBUQUERQUE JR., Durval Muniz de. História: a arte de inventar o passado. Bauru: Edusc, 2007.

ANDRADE, Mário de. Dicionário Musical Brasileiro. Belo Horizonte: Editora Itatiaia, 1989.

BRANDÃO, Carlos Rodrigues. O que é folclore. São Paulo: Brasiliense, 1985.

BURKE, Peter. Cultura Popular na Idade Moderna. São Paulo: Companhia das Letras, 1999.

CHASE, Gilbert. Do Salmo ao Jazz - A música dos Estados Unidos. Porto Alegre: Editora Globo, 1957.

COBB JR., Charles E. Na trilha do Blues. National Geographic, São Paulo, maio. 2004.p.118-141

FLORES, Cantalício Érico. Caderno de cançôes. Acervo pessoal de Daniel Graudin. p.41.

GEBARA, Ivone. O que é saudade. São Paulo: Brasiliense, 2010.

NEPOMUCENO, Rosa. Música caipira: da roça ao rodeio. 2. ed. São Paulo: Ed. 34, 2005. 


\section{Entrevistas}

SANTOS, Zilda Flores; GRAUDIN, Daniel. Entrevista concedida a Carlos Gregório dos Santos Gianelli, em 20 de fevereiro de 2012. Guaramirim/SC.

\section{Filmografia}

MUTIRÁO. Direção: Leon Hirszman. São Paulo: 1975.12min35mm.cor.

CACAU. Direção: Leon Hirszman. São Paulo: 1976(a).11 min 35mm.cor.

CANA-DE-AÇUCAR. Direção: Leon Hirszman. São Paulo: 1976(b).10min 35mm.cor.

\section{Websites}

Conferência "História Oral e Poder" - Alessandro Portelli- XXV Simpósio Nacional de História - Fortaleza 2009:

Parte 1 - http://www.youtube.com/watch?v=7dDCCW1fPH8

Parte 2 - http://www.youtube.com/watch?v=JH4B_Me45Bs

Parte 3 - http://www.youtube.com/watch?v=cr0r3kIGXWU

Parte 4 - http://www.youtube.com/watch?v=hyXGw6PREkQ

http://www.leonhirszman.com.br/

Resumo: $\mathrm{O}$ presente trabalho propóe uma reflexão em relação à temática dos Cantos de Trabalho e sua relação com a metodologia fornecida pela História Oral. São analisadas as diferenças presentes em cada canto, as possibilidades de variação de cada região e suas implicaçóes histórico-culturais. Para este artigo foram utilizados relatos de entrevistados da cidade de Guaramirim, Santa Catarina.

Palavras-chave: Cantos de Trabalho, História Oral, natureza.

\section{When the Nature leads: reports of work songs}

Abstract: This paper proposes a reflection about the theme of Work Songs and its relation with the methodology supplied by Oral History. Are analyzed the differences in each song, the possibilities of variation for each region and the historical and cultural implications. For this article, were used narrations of interviewees in the city of Guaramirim, Santa Catarina.

Keywords: Worksongs, Oral History, Nature. 